\title{
Preconcentration and Determination of Fe(III) from Water and Food Samples by Newly Synthesized Chelating Reagent Impregnated Amberlite XAD-16 Resin
}

\author{
Şerife Tokalığlu, ${ }^{*}$ Hasan Ergün, and Alaaddin Çukurovalı ${ }^{\dagger}$ \\ Erciyes University, Faculty of Arts and Sciences, Chemistry Department, 38039, Kayseri, Turkey \\ *E-mail: serifet@erciyes.edu.tr \\ ${ }^{\dagger}$ Frat University, Faculty of Arts and Sciences, Chemistry Department, 23119, Elazığ, Turkey \\ Received January 29, 2010, Accepted May 19, 2010
}

\begin{abstract}
A simple and reliable method has been developed to selectively separate and concentrate trace amounts of Fe(III) ions from water and food samples by using flame atomic absorption spectrometry. A new reagent, 5-hydroxy-4ethyl-5,6-di-pyridin-2-yl-4,5-dihydro- $2 H$ - $[1,2,4]$ triazine-3-thione, was synthesized and characterized by using FT-IR spectroscopy and elemental analysis. Effects of $\mathrm{pH}$, concentration and volume of elution solution, sample flow rate, sample volume and interfering ions on the recovery of $\mathrm{Fe}$ (III) were investigated. The optimum $\mathrm{pH}$ was found to be 5 . Eluent for quantitative elution was $10 \mathrm{~mL}$ of $2 \mathrm{M} \mathrm{HCl}$. The preconcentration factor of the method, detection limit $\left(3 \mathrm{~s} / \mathrm{b}, \mu \mathrm{g} \mathrm{L}^{-1}\right)$ and relative standard deviation values were found to be $25,4.59$ and $1 \%$, respectively. In order to verify the accuracy of the method, two certified reference materials (TMDA 54.4 lake water and SRM 1568a rice flour) were analyzed. The results obtained were in good agreement with the certified values. The method was successfully applied to the determination of Fe(III) ions in water and food samples.
\end{abstract}

Key Words: Fe(III), Solid phase extraction, A new reagent, Flame atomic absorption spectrometry

\section{Introduction}

As the number of ecological and health problems associated with environmental contamination continues to rise, the determination of trace heavy metals in environmental samples is becoming more and more important. ${ }^{1}$ Iron is widely distributed in nature and is one of the most important elements in environmental and biological systems as many kinds of compounds. Iron is an essential and useful element for organism and an important part of tissue and blood in animal and human being. It plays a central role in the biosphere and serves as the active center of proteins responsible for $\mathrm{O}_{2}$ and electron transfer and is also essential for forming some kinds of biotic enzymes. Although daily requirements for iron are $8-18 \mathrm{mg}$ for man and woman, respectively, it is potentially toxic in excess concentrations. High doses of iron can cause nausea, vomiting, stomach pain and constipation. $^{2-4}$

Preconcentration and separation methods are usually required for the determination of trace elements in complicated matrices, in spite of increasingly sophisticated analytical instrumentation. Recently, solid phase extraction (SPE) has become popular in compared with the more traditional liquid-liquid extraction methods. It is an attractive separation and preconcentration technique for heavy metal ions with some important advantages (simplicity, flexibility, economic, rapid, higher enrichment factors, absence of emulsion, low cost because of lower consumption of reagents, more importantly environment friendly). ${ }^{5,6}$ The impregnated resins are designed by physically loading organic extractants on a solid inert support material.

Amberlite XAD resins are good supports for developing chelating matrices. Important advantages of Amberlite XAD resins over other supports are their good physical properties such as their porosity, uniform pore size distribution, high surface area as chemical homogeneous, non-ionic structure, and good adsorbent properties for great amounts of uncharged compounds. Several studies have been reported for the XAD series resins which are impregnated with various reagents. ${ }^{7-12}$ The large surface area of Amberlite XAD-16 resin $\left(800 \mathrm{~m}^{2} \mathrm{~g}^{-1}\right)$ makes it possible to increase the number of chelating sites and to make them more accessible towards the adsorption of metal ions. ${ }^{13,14}$ Therefore, Amberlite XAD-16 has been selected as a solid phase extraction support for metal chelates in this work.

Many reagents are suggested for determination of iron(III) by solid-phase extraction: gallic acid, ${ }^{13} 4$-(2-pyridylazo)-resorcinol, ${ }^{7}$ chromotropicacid, ${ }^{15,16} N$-benzoyl- $N$-phenyl hydroxylamine, ${ }^{4}$ 2-mercaptobenzimidazol, ${ }^{17} 5$-sulfosalicylic acid, ${ }^{18} 2,3$ dihydroxy benzoic acid, ${ }^{19}$ purpurogallin, ${ }^{20}$ acetylsalicylic acid, ${ }^{21}$ and curcumin. ${ }^{1}$ In this work, a new reagent, 5-hydroxy-4-ethyl5,6-di-pyridin-2-yl-4,5-dihydro-2H-[1,2,4]triazine-3-thione (HL) was synthesized and it was characterized by using FT-IR spectroscopy and elemental analysis. HL impregnated Amberlite XAD-16 was used as adsorbent for the preconcentration of Fe(III) ions and its determination was made by FAAS. Experimental parameters affecting the preconcentration of Fe(III) ions, such as $\mathrm{pH}$, type, concentration and volume of eluent, sample volume, sample flow rate and interfering ions were studied. The optimized method was used for the separation and preconcentration of Fe(III) in various water and food samples.

\section{Experimental}

Instrument. A Perkin Elmer AAnalyst 800 model flame atomic absorption spectrometer (Waltham, MA, USA) was used for the determination of Fe. The most sensitive analytical line used for Fe(III) and slit width were $248.3 \mathrm{~nm}$ and $0.2 \mathrm{~nm}$, respectively. The acetylene/air flow rates were $2.0 / 17 \mathrm{~L} \mathrm{~min}^{-1}$. A Consort C533 model digital pH meter (Belgium) was used for all the $\mathrm{pH}$ measurements. Melting point was determined on a 
Gallenkamp melting point apparatus and is uncorrected. The elemental analyses were carried out by a LECO CHNSO-932 elemental analysis apparatus. The IR spectra were measured by Mattson 1000 FT-IR spectrometer using KBr pellets.

Reagents and solutions. All chemicals used for preparation of solutions were of analytical grade. The Fe(III) stock solution (1000 $\mu \mathrm{g} \mathrm{mL}^{-1}$ ) was prepared by dissolving the appropriate amount of its nitrate salt in doubly distilled water. The working solutions of Fe(III) were obtained by appropriate dilution of the stock solution. The $\mathrm{pH}$ of the solutions was adjusted by use of the following solutions. For the $\mathrm{pH} 1$ and 2, a $\mathrm{KCl} / \mathrm{HCl}$ solution was used. $\mathrm{CH}_{3} \mathrm{COOH} / \mathrm{CH}_{3} \mathrm{COONH}_{4}$ buffer was used to adjust $\mathrm{pH}$ in the range of 3-6, while $\mathrm{NH}_{3} / \mathrm{NH}_{4} \mathrm{Cl}$ buffer was used for $\mathrm{pH}$ 8-10.

Synthesis of reagent. Synthesis of the compound was performed with the minor modification of literature ${ }^{22}$ as follows. A solution of $10 \mathrm{mmol}$ of 2-hydroxy-1,2-di-pyridin-2-yl-ethanone(pyridoin) and $20 \mathrm{mmol}$ of thiosemicarbazide in $50 \mathrm{~mL}$ absolute ethanol was refluxed for $20 \mathrm{~h}$ in the presence of 0.005 $\mathrm{g} p$-toluenesulfonic acid as catalyst, with continuous stirring and monitoring the course of the reaction by IR spectroscopy. Monitoring the visibility of carbonyl group of the starting substance (pyridoin) by IR spectroscopy is easily done and then it is very easy to determine when the reaction is complete. After the completion of the reaction, the reaction mixture was kept at room temperature for one day and then the desired compound was crystallized which was filtered, washed with copious ethanol and dried in air. The structure of the reagent is illustrated in Fig. 1.

Characterization of reagent. The ${ }^{1} \mathrm{H}-\mathrm{NMR},{ }^{13} \mathrm{C}-\mathrm{NMR}$ and $\mathrm{X}$-ray results of the reagent have been reported in the literature. $^{22}$ The FT-IR spectrum of reagent shows peaks at $3175 \mathrm{~cm}^{-1}$ and $3134 \mathrm{~cm}^{-1}$ which are attributed to $v_{\mathrm{OH}}$ and $v_{\mathrm{NH}}$, respectively. The peaks at $2928-2986 \mathrm{~cm}^{-1}$ correspond to the C-H stretching of the aliphatics. The absorptions $1519 \mathrm{~cm}^{-1}, 1243$ $\mathrm{cm}^{-1}, 1070 \mathrm{~cm}^{-1}$ and $634 \mathrm{~cm}^{-1}$ could be assigned to the thioamide I, thioamide II, thioamide III, and thioamide IV, respectively.

The elemental analysis results of the reagent $\left(\mathrm{C}_{15} \mathrm{H}_{15} \mathrm{~N}_{5} \mathrm{OS}\right)$ are as follows: found (\%): C, 57.65; H, 5.03; N, 22.71; S, 9.96; calculated (\%): C, 57.49; H, 4.82; N, 22.35; S, 10.23. The results have shown that there is a good agreement between experimental and theoretical values.

Chelating resin and column preparation. Amberlite XAD-16 resin was treated with $1 \mathrm{M}$ nitric acid and $1 \mathrm{M} \mathrm{NaOH}$ solutions, and then washed with distilled water until $\mathrm{pH}$ of supernatant was neutral. The resin was dried in an oven at $110{ }^{\circ} \mathrm{C} .0 .5 \mathrm{~g}$ of the resin was saturated for $2 \mathrm{~h}$ with $10 \mathrm{~mL}$ of $0.1 \%(\mathrm{w} / \mathrm{v}) \mathrm{HL}$ solution by stirring in a beaker. The chelating resin was filtered, washed with water and dried in an oven at $110{ }^{\circ} \mathrm{C}$. The pre-

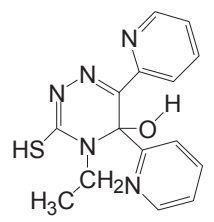

Figure 1. The structure of the 5-hydroxy-4-ethyl-5,6-di-pyridin-2yl-4,5-dihydro- $2 H$-[1,2,4] triazine-3-thione. pared resin was slurried in water and poured into glass column ( $1 \mathrm{~cm}$ in diameter $\times 10 \mathrm{~cm}$ in length) in which the column contains a small amount of glass wool on the disc. The impregnated resin was rinsed with distilled water and conditioned with 10 $15 \mathrm{~mL}$ of $\mathrm{pH} 5$ buffer solution prior to passage of the sample solution.

General procedure. The $\mathrm{pH}$ of the $25 \mathrm{~mL}$ of the model solution containing $20 \mu \mathrm{g}$ of $\mathrm{Fe}$ (III) was adjusted to $\mathrm{pH} 5$ by additon of acetic acid/sodium acetate buffer solution. The column was preconditioned by passing the related buffer solution. The model solution was passed through the column at a flow rate of $2 \mathrm{~mL} \mathrm{~min}^{-1}$. The retained metal ions were eluted with $10 \mathrm{~mL}$ of $2 \mathrm{M} \mathrm{HCl}$. The determinations of metal ions in eluate were made by FAAS. After each use, the resin in the column was washed with large volumes of water and stored for the next experiment.

Sample preparation. Tap water samples were taken from our laboratory and analysed without pre-treatment. The bottled water was purchased from a local market. The well water from Kayseri and wastewater samples from Kayseri Organized Industrial Region were collected in pre-washed polyethylene bottles, filtered through a Millipore cellulose membrane filter with a $0.45 \mu \mathrm{m}$ pore size and acidified to $\mathrm{pH} 2$ with $\mathrm{HNO}_{3}$. In order to oxidize organic matter in wastewater sample, concentrated $\mathrm{HNO}_{3}$ and concentrated $\mathrm{H}_{2} \mathrm{O}_{2}$ were used.

The food samples (macoroni, wheat and flour) were purchased from a local market in Kayseri. $0.50 \mathrm{~g}$ of sample was placed in a $100 \mathrm{~mL}$ beaker and $10 \mathrm{~mL}$ of concentrated $\mathrm{HNO}_{3}$ $(65 \% \mathrm{w} / \mathrm{w})$ was added to the beaker. The mixture was evaporated near to dryness on a hot plate at about $130{ }^{\circ} \mathrm{C}$. After cooling to room temperature, $3 \mathrm{~mL}$ of concentrated hydrogen peroxide $(30 \%, \mathrm{w} / \mathrm{w})$ was added. The mixture was again evaporated to dryness. The resulting solution was diluted to $25 \mathrm{~mL}$ with distilled water. ${ }^{23}$ The solid phase extraction method described above was applied to this samples. The Fe(III) in the water and food samples was determined by FAAS.

\section{Results and Discussion}

Effect of pH. $\mathrm{pH}$ is a very important factor for metal-chelate formation and solid phase extraction processes. For this purpose, the $\mathrm{pH}$ of $\mathrm{Fe}(\mathrm{III})$ spiked model solutions $(20 \mu \mathrm{g})$ was adjusted in a range of $1-10$ by using the related buffer solutions. The

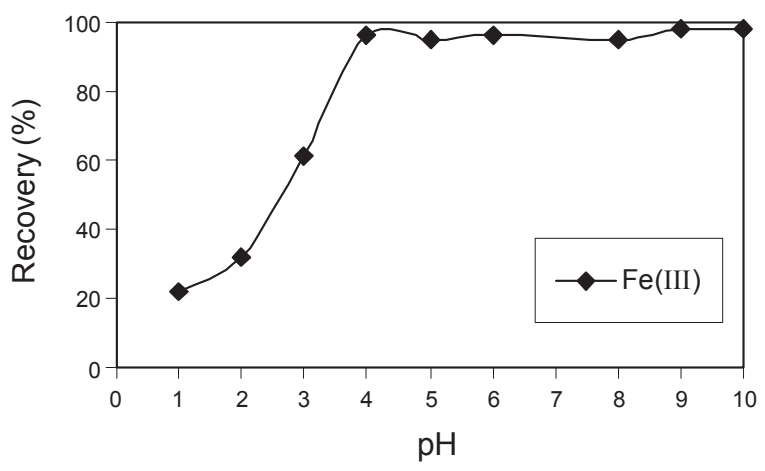

Figure 2. Effect of $\mathrm{pH}$ on the recovery of Fe(III) (resin amount: $0.50 \mathrm{~g}$, eluent: $10 \mathrm{~mL}$ of $2 \mathrm{MHCl}$ ). 
Table 1. Effect of volume and concentration of $\mathrm{HNO}_{3}$ and $\mathrm{HCl}$ on the recovery of $\mathrm{Fe}(\mathrm{III}), n=3$

\begin{tabular}{ccc}
\hline Concentration of eluent & Volume $(\mathrm{mL})$ & $\mathrm{R} \pm \mathrm{s}(\%)$ \\
\hline $0.5 \mathrm{M} \mathrm{HNO}_{3}$ & 20 & $75 \pm 2$ \\
$1 \mathrm{M} \mathrm{HNO}_{3}$ & 5 & $28 \pm 1$ \\
& 10 & $85 \pm 3$ \\
$1.5 \mathrm{M} \mathrm{HNO}_{3}$ & 20 & $87 \pm 2$ \\
$2 \mathrm{M} \mathrm{HNO}_{3}$ & 20 & $89 \pm 1$ \\
& 5 & $80 \pm 4$ \\
$3 \mathrm{M} \mathrm{HNO}_{3}$ & 10 & $95 \pm 2$ \\
$0.5 \mathrm{M} \mathrm{HCl}^{\mathrm{M} \mathrm{HCl}}$ & 20 & $96 \pm 2$ \\
& 20 & $95 \pm 2$ \\
& 20 & $76 \pm 2$ \\
$1.5 \mathrm{M} \mathrm{HCl}$ & 5 & $69 \pm 1$ \\
$2 \mathrm{M} \mathrm{HCl}$ & 10 & $90 \pm 3$ \\
& 20 & $98 \pm 1$ \\
& 20 & $98 \pm 1$ \\
& 5 & $81 \pm 1$ \\
& 10 & $96 \pm 3$ \\
& 20 & $95 \pm 2$ \\
\hline
\end{tabular}

retained ions were eluted by $10 \mathrm{~mL}$ of $2 \mathrm{M} \mathrm{HCl}$. The graph of retention as a funtion of $\mathrm{pH}$ is shown in Fig. 2. The quantitative recovery $(\geq 95 \%)$ for $\mathrm{Fe}(\mathrm{III})$ was found in the range of the $\mathrm{pH}$ 4 - 10. For all subsequent experiments, $\mathrm{pH} 5$ was selected as optimal. The experiment was also repeated without reagent at $\mathrm{pH}$ 5. In this case, the recovery value for Fe(III) was found as $69 \%$.

Effect of elution conditions. The elution of iron(III) from HL impregnated resin was studied by using various eluting reagents which are $0.5-3 \mathrm{M} \mathrm{HNO}_{3}$ and $0.5-2 \mathrm{M} \mathrm{HCl}$ at various volumes of $5-20 \mathrm{~mL}$. The results are illustrated in Table 1.10 $\mathrm{mL}$ of $2 \mathrm{M} \mathrm{HCl}$ solution was preferred as eluent due to the low acid concentration, volume and the formation of anionic chloro complexes of $\mathrm{Fe}(\mathrm{III})$. The eluent concentration and its volume must be as low as possible because of both the re-use of chelating resin and to obtain high preconcentration factor, respectively.

Effect of sample flow rate. The flow rate of the sample solution is a very important parameter for controlling the time of adsorption and analysis. The effect of flow rate of sample solution on metal ion sorption was studied in a range of $2-8 \mathrm{~mL}$ $\mathrm{min}^{-1}$. It was found that the retention of $\mathrm{Fe}$ (III) was changed in the range of $91-97 \%$ for $2-4 \mathrm{~mL} \mathrm{~min}^{-1}$ flow rates. The flow rate of $2 \mathrm{~mL} \mathrm{~min}^{-1}$ was subsequently used in further experiments.

Effect of sample volume. In order to determine the maximum applicable sample volume and maximum reachable enrichment factor, the effect of sample volume on the recovery of Fe(III) was studied. For this purpose, $50-500 \mathrm{~mL}$ volumes of model solutions containing $20 \mu \mathrm{g} \mathrm{Fe}(\mathrm{III})$ were passed through the column under optimum experimental conditions. The results are depicted in Fig. 3. The recovery for Fe(III) was quantitative for volumes of $50-250 \mathrm{~mL}$. For $300 \mathrm{~mL}$ of sample volume, the recovery value was $90 \%$. For an elution volume of $10 \mathrm{~mL}$, a preconcentration factor of 25 was achieved.

Effect of foreign ions. The effect of some foreign ions $\left(\mathrm{Na}^{+}\right.$, $\mathrm{K}^{+}, \mathrm{Ca}^{2+}, \mathrm{Mg}^{2+}, \mathrm{SO}_{4}{ }^{2-}, \mathrm{NO}_{3}^{-}$and $\left.\mathrm{PO}_{4}^{3-}\right)$ found in natural samples on the determination of Fe(III) was examined. The ions
Table 2. Effect of matrix ions on the recovery of Fe (III), $n=3$

\begin{tabular}{ccccc}
\hline Ion & Salt & $\begin{array}{c}\text { Concentrations } \\
\left(\mathrm{mg} \mathrm{L}^{-1}\right)\end{array}$ & $\mathrm{R} \pm \mathrm{s}(\%)$ & $\begin{array}{c}\text { Interfering ion/ } \\
\text { analyte ratio }\end{array}$ \\
\hline $\mathrm{Na}^{+}$ & $\mathrm{NaCl}$ & 250 & $95 \pm 4$ & 313 \\
& & 500 & $91 \pm 2$ & 625 \\
& & 1000 & $86 \pm 2$ & 1250 \\
$\mathrm{~K}^{+}$ & $\mathrm{KCl}$ & 250 & $96 \pm 2$ & 313 \\
& & 500 & $91 \pm 2$ & 625 \\
& & 1000 & $88 \pm 2$ & 1250 \\
$\mathrm{Ca}^{2+}$ & $\mathrm{Ca}\left(\mathrm{NO}_{3}\right)_{2} \cdot 4 \mathrm{H}_{2} \mathrm{O}$ & 250 & $93 \pm 2$ & 313 \\
& & 500 & $85 \pm 1$ & 625 \\
& & 1000 & $84 \pm 2$ & 1250 \\
$\mathrm{Mg}^{2+}$ & $\mathrm{Mg}\left(\mathrm{NO}_{3}\right)_{2} \cdot 6 \mathrm{H}_{2} \mathrm{O}$ & 250 & $98 \pm 2$ & 313 \\
& & 500 & $86 \pm 2$ & 625 \\
& & 1000 & $82 \pm 2$ & 1250 \\
$\mathrm{Cl}^{-}$ & $\mathrm{NaCl}^{3-}$ & 500 & $94 \pm 3$ & 625 \\
$\mathrm{PO}_{4}{ }^{3-}$ & $\mathrm{Na}_{3} \mathrm{PO}_{4}$ & 250 & $95 \pm 2$ & 313 \\
$\mathrm{SO}_{4}{ }^{2-}$ & $\mathrm{Na}_{2} \mathrm{SO}_{4}$ & 250 & $94 \pm 3$ & 313 \\
\hline
\end{tabular}

${ }^{a} \mathrm{Fe}(\mathrm{III}): 0.8 \mathrm{mg} \mathrm{L}^{-1}$.

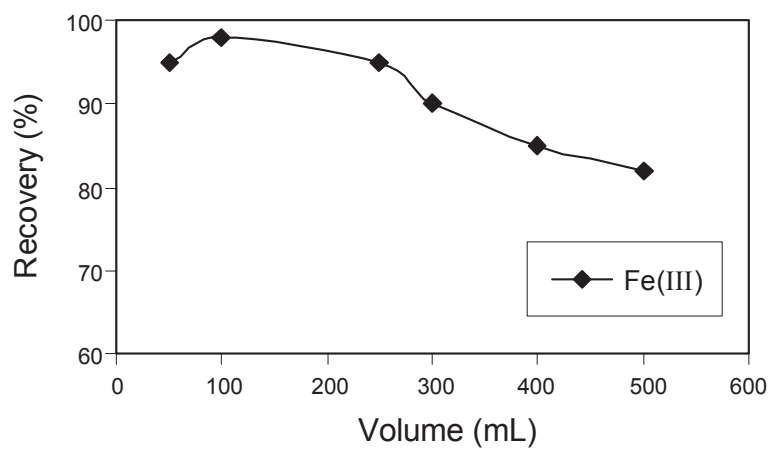

Figure 3. Effect of sample volume on the recovery of Fe(III).

were added individually to model solutions containing fixed amount of $\mathrm{Fe}$ (III) as their nitrate or chloride salts. The results are listed in Table 2. The tolerance limits of interfering ions on $\mathrm{Fe}(\mathrm{III})$ were high. $1000 \mathrm{mg} \mathrm{L}^{-1} \mathrm{Na}^{+}$and $\mathrm{K}^{+}, 500 \mathrm{mg} \mathrm{L}^{-1} \mathrm{Ca}^{2+}$ and $\mathrm{Mg}^{2+}$ had an interfering effect on the recovery of $\mathrm{Fe}(\mathrm{III})$.

Analytical performance. In order to determine the detection limit (DL) of the described method, a $25 \mathrm{~mL}$ of blank solutions $(n=15)$ was passed through the column under the optimal experimental conditions. The DL calculated as three times the standard deviation of the blank solutions divided by the slope of the calibration curve was $4.59 \mu \mathrm{g} \mathrm{L}^{-1}$ for Fe(III). The precision of the method under the optimum conditions ( $\mathrm{pH} 5$, flow rate of sample: $2 \mathrm{~mL} \mathrm{~min}^{-1}$ ) was determined by performing successive 10 retention and elution cycles followed by FAAS. The recovery of $\mathrm{Fe}(\mathrm{III})$ was found to be $95 \pm 1 \%$.

Accuracy and applications of the method. The accuracy of the proposed method was verified by determination of Fe(III) ion in the two standard reference materials, TMDA-54.4 fortified lake water and SRM 1568 a rice flour. The results in Table 3 show that the described method was in a good agreement with the certified values and the method is applicable for the determination of $\mathrm{Fe}(\mathrm{III})$ in the water and food samples. In 
Table 3. The analysis results of standard reference materials $(n=3)$

\begin{tabular}{|c|c|c|c|c|c|c|}
\hline \multirow{2}{*}{ Element } & \multicolumn{3}{|c|}{ TMDA 54.4 fortified lake water } & \multicolumn{3}{|c|}{ SRM 1568a rice flour } \\
\hline & Certified $^{a}\left(\mu \mathrm{g} \mathrm{L}^{-1}\right)$ & Found $^{a}\left(\mu \mathrm{g} \mathrm{L}^{-1}\right)$ & $\mathrm{R}(\%)$ & Certified $^{a}\left(\mu \mathrm{g} \mathrm{g}^{-1}\right)$ & Found $^{a}\left(\mu \mathrm{g} \mathrm{g}^{-1}\right)$ & $\mathrm{R}(\%)$ \\
\hline $\mathrm{Fe}(\mathrm{III})$ & $382 \pm 5$ & $379 \pm 5$ & 99.2 & $7.4 \pm 0.9$ & $7.5 \pm 0.2$ & 101 \\
\hline
\end{tabular}

${ }^{a} \bar{x} \pm t s / \sqrt{n}$, at $95 \%$ confidence level.

Table 4. Determination of Fe(III) in water samples

\begin{tabular}{|c|c|c|c|}
\hline \multirow{2}{*}{ Sample } & \multicolumn{3}{|c|}{ Concentration $(\bar{x} \pm t s / \sqrt{n})^{a}$} \\
\hline & Added $\left(\mu \mathrm{g} \mathrm{L}^{-1}\right)$ & Found $\left(\mu \mathrm{g} \mathrm{L}^{-1}\right)$ & Recovery (\%) \\
\hline \multirow{3}{*}{ Tap water } & - & $<\mathrm{DL}$ & - \\
\hline & 100 & $106 \pm 14$ & 106 \\
\hline & 200 & $206 \pm 13$ & 103 \\
\hline \multirow{3}{*}{ Bottled water } & - & $9.63 \pm 6.85$ & - \\
\hline & 50 & $61.2 \pm 7.9$ & 103 \\
\hline & 100 & $109 \pm 7$ & 99 \\
\hline \multirow{3}{*}{ Well water } & - & $30.9 \pm 6.0$ & \\
\hline & 50 & $76.9 \pm 6.0$ & 92 \\
\hline & 100 & $131 \pm 5$ & 100 \\
\hline \multirow{3}{*}{ Wastewater $^{b}$} & - & $0.97 \pm 0.20$ & \\
\hline & 1.0 & $1.96 \pm 0.20$ & 99 \\
\hline & 2.0 & $3.00 \pm 0.35$ & 102 \\
\hline
\end{tabular}

${ }^{a}$ At $95 \%$ confidence level $(n=3) .{ }^{b} \mu \mathrm{g} \mathrm{mL}^{-1}$.

addition, the accuracy of the method was tested performing the recovery studies for the water samples. The known amounts of $\mathrm{Fe}$ (III) ions were added to aliquots of $100 \mathrm{~mL}$ of the tap water samples, of $200 \mathrm{~mL}$ of bottled water and well water, and of 10 $\mathrm{mL}$ of wastewater sample. As shown in Table 4, the recoveries of the analytes in all the samples were in the range of 92 $106 \%$. This results indicated that the developed preconcentration method for $\mathrm{Fe}$ (III) was not affected by potential inter- ferences from the major matrix components of the analysed samples. The method was also applied for the determination of Fe(III) in some food samples. The Fe(III) concentrations $(\bar{x} \pm t s / \sqrt{n}, n=3)$ in the macaroni, wheat and flour samples were found to be $22.2 \pm 4.0,23.8 \pm 1.7$ and $19.5 \pm 4.7 \mu \mathrm{g} \mathrm{g}^{-1}$, respectively.

\section{Conclusion}

A new chelating reagent was synthesized, characterized and it was used for column solid phase extraction of $\mathrm{Fe}$ (III) using Amberlite XAD-16 loaded with HL. The developed method was successfully employed for the analysis of food and water samples. The method is simple, low cost and eco-friendly. Fe(III) was quantitatively retained in the wide $\mathrm{pH}$ range. A good preconcentration factor ( 25 fold) and detection limit value $(4.59 \mu \mathrm{g}$ $\mathrm{L}^{-1}$ ) for Fe(III) were obtained. The found results for certified reference materials were in a good agreement with the reference values. Table 4 shows the comparison of the described method with other solid phase extraction methods reported in the literature for the determination of Fe(III) ions. The reusability of the chelating resin (at least for 50 cycles) is much higher than the other chelating matrices. The RSD\% values of the method are lower than those of the other methods. The elution of analyte can easily perform with a low acid concentration and volume. The other advantages of the method are acidic working $\mathrm{pH}$ and good tolerance limit towards many interfering ions.

Table 5. Comparison of the described method with the some solid phase extraction methods for Fe(III) determination

\begin{tabular}{|c|c|c|c|c|c|c|}
\hline Impregnated resin/detection technique & $\mathrm{pH} /$ eluent & $\begin{array}{l}\text { Reusability of } \\
\text { the adsorbent }\end{array}$ & $\mathrm{PF}$ & $\begin{array}{c}\mathrm{DL} \\
\left(\mu \mathrm{g} \mathrm{L}^{-1}\right)\end{array}$ & $\begin{array}{l}\text { RSD } \\
(\%)\end{array}$ & Reference \\
\hline Silica gel modified with curcumin/ICP-OES & $4 / 2 \mathrm{~mL}$ of $0.1 \mathrm{M} \mathrm{HCl}$ & - & 75 & 0.15 & $<3$ & {$[1]$} \\
\hline BPHA loaded microcrystalline naphthalene/ICP-OES & $3 / 0.1 \mathrm{~mL}$ of $1 \mathrm{M} \mathrm{HCl}$ & - & 156 & 0.053 & 4.2 & {$[2]$} \\
\hline Amberlite XAD-1180 resin loaded with PAR/FAAS & $9.5 / 20 \mathrm{~mL}$ of $3 \mathrm{M} \mathrm{HNO}_{3}$ & 15 & 125 & 1.25 & 4.1 & {$[7]$} \\
\hline Chromotropic acid coated alumina/FAAS & $8 / 2 \mathrm{ml}$ of $1 \mathrm{M} \mathrm{HNO}_{3}$ & 15 & 100 & 0.54 & - & {$[16]$} \\
\hline $\begin{array}{l}\text { Nanometer } \mathrm{SiO}_{2} \text { modified with 5-sulfosalicylic acid/ } \\
\text { FAAS }\end{array}$ & $3.5 / 2 \mathrm{~mL}$ of $0.01 \mathrm{M} \mathrm{HCl}$ & 10 & 100 & 0.09 & $<3$ & {$[18]$} \\
\hline Analcime zeolite modified with Schiff base/FAAS & $3.5 / 10 \mathrm{~mL}$ of $0.1 \mathrm{M}$ EDTA & - & 60 & 0.084 & 1.13 & {$[24]$} \\
\hline Amberlite XAD-7 impregnated with XO/FAAS & $4 / 10 \mathrm{~mL}$ of $2 \mathrm{M} \mathrm{HCl}$ & 20 & 200 & 6 & 1.1 & {$[25]$} \\
\hline $\begin{array}{l}\text { Methyltrioctyl ammonium chloride supported on } \\
\text { naphthalene/FAAS }\end{array}$ & $4 / 5 \mathrm{~mL}$ of $3 \mathrm{M} \mathrm{HNO}_{3}$ & - & 100 & 3.1 & $1.9-3.4$ & {$[26]$} \\
\hline $\begin{array}{l}\text { Tetraoctylammonium bromide supported on } \\
\text { naphthalene/FAAS }\end{array}$ & $3 / 5 \mathrm{~mL}$ of $1.5 \mathrm{M} \mathrm{HNO}_{3}$ & - & 36 & 12 & 1.8 & {$[27]$} \\
\hline Amberlite XAD-16 loaded with HL/FAAS & $5 / 10 \mathrm{~mL}$ of $2 \mathrm{M} \mathrm{HCl}$ & 50 & 25 & 4.59 & 1.0 & This work \\
\hline
\end{tabular}


Acknowledgments. The authors are grateful for the financial support of the Unit of the Scientific Research Projects of Erciyes University (project no: FBY-09-703).

\section{References}

1. Zhu, X.; Chang, X.; Cui, Y.; Zou, X.; Yang, D.; Hu, Z. Microchem. J. 2007, 86, 189

2. Xiong, C.; Jiang, Z.; Hu, B. Anal. Chim. Acta 2006, 559, 113.

3. Yaman, M.; Kaya, G. Anal. Chim. Acta 2005, 540, 77.

4. Tokalıoğlu, Ş.; Livkebabc1, A. Microchim. Acta 2009, 164, 471.

5. Hazer, O.; Kartal, S.; Tokalıŏlu, S. J. Anal. Chem. 2009, 64, 609.

6. Rofouei, M. K.; Payehghadr, M.; Shamsipur, M.; Ahmadalinezhad, A. J. Hazard. Mater. 2009, 168, 1184.

7. Tokalığlu, Ş.; Kartal, Ş. Bull. Korean Chem. Soc. 2006, 271, 293.

8. Singh, B. N.; Maiti, B. Talanta 2006, 69, 393.

9. Ayata, S.; Kaynak, İ; Merdivan, M. Environ. Monit. Assess. 2009, 153, 333.

10. Hosseini, M. S.; Bandegharaei, A. H.; Raisi, H.; Belador, F. J. Hazard. Mater. 2009, 169, 52.

11. Matsumiya, H.; Yasuno, S.; Iki, N.; Miyano, S. J. Chromatogr. A 2005, 1090, 197.

12. Ramesh, A.; Mohan, K. R.; Seshaiah, K. Talanta 2002, 57, 243.
13. Sharma, R. K.; Pant, P. J. Hazard. Mater. 2009, 163, 295.

14. http://www.sigmaaldrich.com

15. Tewari, P. K.; Singh, A. K. Analyst 1999, 124, 1847.

16. Ramesh, A.; Devi, B. A.; Hasegawa, H.; Maki, T.; Ueda, K. Microchem. J. 2007, 86, 124.

17. Bagheri, H.; Gholami, A.; Najafi, A. Anal. Chim. Acta 2000, 424, 233.

18. Cui, Y.;Chang, X.; Zhu, X.; Jiang, N.; Hu, Z.; Lian, N. Microchem. J. 2007, 86, 23.

19. Hosseini, M. S.; Raisi, H.; Madarshahian, S. React. Funct. Polym. 2006, 66, 1539.

20. Mahmoud, M. E.; Al Sadi, M. S. M. Anal. Chim. Acta 2001, 450, 239.

21. Zhu, X.; Yang, D.; Chang, X.; Cui, Y.; Hu, Z.; Zou. X. Microchim. Acta 2008, 161, 115 .

22. Çukuroval1, A. Synthetic Commun. 2009, 39, 4396.

23. Oymak, T.; Tokalıoğlu, Ş.; Yılmaz, V.; Kartal, Ş.; Aydın, D. Food Chem. 2009, 113, 1314.

24. Shamspur, T.; Sheikhshoaie, I.; Mashhadizadeh, M. H. J. Anal. At. Spectrom. 2005, 20, 476.

25. Tewari, P. K.; Singh, A. K. Fresenius J. Anal. Chem. 2000, 367, 562

26. Pourreza, N.; Hoveizavi, R. Anal. Chim. Acta 2005, 549, 124

27. Pourreza, N.; Mousavi, H. Z. Talanta 2004, 64, 264. 